This is the post print version of the article, which has been published in Journal of Beliefs \& Values. 2018, 39 (2), 157-168. http://dx.doi.org/10.1080/13617672.2018.1450804

The Institutional Repository of University of Tampere

What kind of tensions are involved in the pedagogical use of religious narratives? Perspectives from Finnish Evangelic Lutheran and Islamic religious education.

Raili Keränen-Pantsu (corresponding author)

Researcher, MEd, Philosophical Faculty, School of Applied Sciences and Teacher Education, University of Eastern Finland, Joensuu, Finland

Postal details: Kalamestarinpolku 9 C 11, 04300 Tuusula, Finland

Phone: +358407621429

railike@student.uef.fi

Inkeri Rissanen

University lecturer, Faculty of Education, University of Tampere, Finland

Postal details: Faculty of Education, 33014 University of Tampere, Finland

inkeri.rissanen@uta.fi 


\section{What kind of tensions are involved in the pedagogical use of religious narratives? Perspectives from Finnish Evangelic Lutheran and Islamic religious education.}

In this article, we examine how narratives of religious traditions are used as resources in religious education and compare practices from Evangelic Lutheran and Islamic religious education in Finnish public schools. The sacredness of narratives from holy books entails that there can be contestations over their pedagogical use, and teachers need to negotiate the possible tensions between the pedagogical aims of liberal religious education and the integrity of the holy narratives. The research data consists of interviews with teachers of Lutheran $(n=4)$ and Islamic $(n=5)$ religious education as well as classroom observations. The results of qualitative content analysis show that teachers use narratives as pedagogical resources when teaching about and from religion. However, tensions occurred between the ideals of student-centred, experiential and creative learning, on one hand, and respecting the sacredness of the narratives, on the other. We also present teachers' ways of negotiating the tensions as well as some differences between Lutheran and Islamic religious education in the pedagogical use of narratives.

Keywords: religious education; Islamic religious education, Evangelic Lutheran religious education, narrative

\section{Introduction}

This qualitative study explores how narratives of religious traditions are used as resources in religious education (RE) and compares practices of Evangelic Lutheran (LRE) and Islamic religious education (IRE) in Finnish public schools. In regard to religious education in European schools, a trend of moving from confessional denominational towards liberal religious education can be detected. This means that the traditional understanding of religious education as a transmission of faith has widely given way to more modern understandings of RE, where the aims of liberal 
religious education come close to multicultural or intercultural education, antiracist education and citizenship education and develop skills of communication, such as interpretation, criticism and dialogue and give pupils agency (see e.g. Jackson, 2004). In Finland, religious education "according to the student's own religion" is given in public schools. Religious education is organised denominationally, but its aims are committed to liberal educational values, such as autonomy, rationality and tolerance (see e.g. Halstead \& Taylor, 1996) and material from religious traditions is understood as resource for the development of the student's individual identity. Thus, it aims to teach about and from religion but there is no intention to socialise students into religion (Grimmit 1987; see also Geoff 2004).

However, liberal forms of religious education have also been accused of renouncing the selfunderstandings of religious traditions and fitting them into a liberal worldview (Barnes 2006), and, for instance, many kinds of value negotiations are found to be involved in teaching Islam in a modern liberal context (Rissanen 2014). In particular, the aim of teaching from religion in the context of liberal religious education demands more in-depth scrutiny. Religious traditions provide plenty of material, such as sacred stories, that can be used as pedagogical resources in supporting the development of the students' identity also in school context. However, the sacredness of these resources entails that there can be contestations over their pedagogical use. More research is needed on how RE teachers negotiate the possible conflicts between the pedagogical aims and the integrity of the holy narratives.

\section{Pedagogical use of religious narratives}

There is no commonly shared definition of narrative in the research field, but there is an 'everyday understanding' of the term. (See e.g. Rudrum, 2006). Riessman (2008, 3) uses the terms narrative 
and story interchangeably, as do we in this article. We make sense of our experiences by narrating them; it has even been stated that to be human is to tell stories and that is what separates humans from all the other beings on Earth (Fisher 1984). Narration is a sense-making act whereby we construct a coherent entity out of our experiences. This leads to the idea of narrative identity since we construct and interpret our experience of who we are by narrative means (see e.g. Ricoeur 1992). Learning, also, can be regarded as a narrative process, which takes place through stories. Clark and Rossitter (2008) distinguish three different levels of narrative learning. According to them, people learn from (1) hearing stories, e.g. religious parables, myths and personal experiences (2) telling stories, and (3) recognising the narratives that shape sociocultural context and cultural conventions. Recognition of narratives enables people to view these underlying cultural assumptions and to examine and critique them.

Stories are always told for a reason and, as Riessman (2008) describes, stories are "strategic, functional and purposeful". This is well-suited to the school context where teachers' pedagogical thinking and curriculum set the framework for the educational use of narratives. There has been a rising interest towards teachers' pedagogical thinking since the 1980s when Clark and Petersen (1986) published their widely noted article "Teachers" thought processes". Teachers make educational decisions all the time. One key question in this research field is how do teachers justify their decisions and what kinds of reasons guide the actions in classroom (Kansanen et al. 2000). In this study, we are interested in teachers' pedagogical thinking and decision-making in the context of liberal religious education, and, in particular, in how teachers negotiate between the selfunderstanding of religious traditions and the liberal educational values as represented in the curriculum. 
Thus, this study focuses on the pedagogical use of a particular set of narratives, namely, religious narratives from the holy scriptures - The Bible, the Qur' an and Hadith. ${ }^{1}$ In the study of religion, these narratives are seen as cultural products that maintain and convey religious values and are considered sacred by the religious traditions. Traditions under scrutiny in this study - Christianity and Islam - are largely based on sacred narratives. When processing narratives that are a part of cultural and religious tradition, the question of who is entitled to interpret these narratives is easily raised. From a religious studies' perspective, all these narratives are 'products of their time' and interpreted in various ways in different cultural and religious contexts, so in order to understand these stories, you should understand something about the origins, cultural contexts and interpretative traditions of the texts - aspects that are present also in the Finnish curricula for religions (Finnish National Agency of Education 2014). However, when religious traditions teach about their holy books, preserving the originality of the texts is a common ideal: for example, memorisation and recitation of the Qur'an are typically seen as central aspects of traditional Islamic education. (see e.g. Berglund 2017; Nakib 2015). Nevertheless, in the context of liberal education and socio-constructivist learning theory, which also serve the ground for the Finnish RE curriculum, the ideals of student-centred learning are embraced (see. e.g. Kallioniemi \& Ubani, 2016) and it is obvious that pedagogical use of religious narratives is never totally free from interpretation. For example, sacred narratives include material which supports liberal educational values - but also material that contradicts them. From the perspective of modern readers, the Bible, for example, seems to support patriarchy, anti-Judaism, slavery, violence and intolerance if the readers fail to go beyond the text and have a critical dialogue with it (Pollefeyt and Bieringer 2005). Thus, RE teachers have to negotiate between the aims of the curriculum and religious traditions' selfunderstanding of the position of the texts and, as Copley (2007) points out, teachers as narrators

\footnotetext{
${ }^{1}$ Hadith are records of traditions or sayings of the Prophet Muhammad, which have served as source for Muslim religious norms and moral guidance, second only to the authority of the Quran, the holy book of Islam. (See e.g. http://academic.eb.com.ezproxy.uef.fi:2048/levels/collegiate/article/Hadith/105855)
} 
hold the power, since they are the ones who represent the narrative in certain light and with certain interpretation.

\section{Islamic and Lutheran religious education in Finnish context}

Most of Finland's population (nowadays roughly 72 per cent) belong to the Evangelic Lutheran Church. Over the past few decades, the number of Muslims in Finland has rapidly increased, but the Muslim population is still relatively small - approximately 1 per cent of the Finnish population (Martikainen 2010). When awareness of the Islamic presence in Finland rose in the 1990s, it was considered alien and threatening, and the general opinion concerning Muslims remains negative (Martikainen, 2010; Sakaranaho 2006, 252-253). However, educational policies are a good example of efforts that have been made to make the Finnish mainstream population more sensitive to cultural and religious diversity.

The Finnish system for religious education is unique compared to most other European countries. (see Kallioniemi \& Ubani, 2016). Students have the right to receive their own religious education, if at least three students belonging to the same religious tradition reside in the same area. Currently, there are curricula for 11 different religions, and those students who do not belong to any religious tradition study secular Ethics instead. This seems a very segregated system, but, in practical terms, approximately 90 per cent of students in basic education (7-16-year-olds) participate in Evangelical Lutheran education, 2 per cent of students participate in Islamic RE. The quota for other religions is 2 per cent and 6 per cent of students participate in secular Ethics. (Educational statistics in Finland, 2017). Basically, Evangelic Lutheran RE, Orthodox RE and secular Ethics are being taught across the country, Islamic RE in the largest cities and minority religions only in certain schools or areas. 
In Finnish schools, IRE takes a form of "general Islam" and different branches of Islam do not have their own curricula.

It is worth noting that despite the fact that RE in Finland is denominationally organised, it is nonconfessional in nature and religious practice in the classroom is prohibited. The contents of teaching also cover other religions and worldviews. RE teachers' qualification demands a master's degree from a university, including pedagogical studies and subject studies. Teachers are hired by the municipal government, not by religious communities. Teachers are not required to belong to the religion or denomination they teach (Kallioniemi \& Ubani, 2016). The Finnish national core curricula for basic education emphasises liberal educational ideals related to students' autonomy and agency (e.g. developing into one's full potential as human being, building understanding of oneself and of society), ideals related to tolerance and respect for difference (e.g. the ability to view issues from the perspectives of others and the ability to engage in intercultural interaction) and ideals related to rationality (e.g. critical thinking) as the underlying values of basic education. Basic education aims to lay the foundation for the development of active global citizenship. (Finnish National Agency for Education, 2014). These values are present also in the curricula for religions, which also emphasise the development of critical thinking, autonomous identity and intercultural/interreligious skills.

In both Islamic and Evangelic Lutheran religious education, learning from religious narratives is a significant part of the teaching, especially in primary school. In secondary school, the focus shifts towards teaching about holy scriptures and, for instance, different interpretative traditions of holy scriptures are covered. Objectives related to the learning environments and working methods of religion continue to transmit liberal educational values and socio-constructive learning concept since they guide the teacher to use creative, functional and experimental methods, projects and 
discussions that support the pupil as a holistic and active learner. This student-centred approach requires teachers to support teaching where pupils actively construct knowledge in multiple ways. Stories, music, visual arts, play and drama are mentioned as examples of implementing such teaching. Narratives are seen both as learning content and as teaching methods in religious education (Finnish National Agency for Education, 2014).

\section{Data and methods}

In this study, we examine the pedagogical use of sacred and traditional narratives in Finnish religious education. Our research questions are:

1) How are religious traditions' narratives used in Lutheran and Islamic religious education?

2) What kind of tensions are involved in the pedagogical use of sacred religious narratives and how do the teachers negotiate these tensions?

3) What kinds of differences are there in the practices, tensions, and negotiations between Lutheran and Islamic religious education?

This qualitative case study combines data from two originally separate study projects. The first study focuses on teachers' pedagogical thinking and use of narrative pedagogy in classroom, especially in religious education. Its data contains interviews with teachers of Islamic religious education ( $n=2$, teachers 4-5, IRE) and Evangelic Lutheran religious education $(n=4$, teachers $1-4$, 6, LRE). The main data is also complemented with ethnographic data collected from lessons. The second study is a multi-site ethnographic study that focuses on Islamic religious education in Finland, and its data includes observations of three separate Islamic religious education courses in lower and upper secondary levels, and interviews with the teachers of these courses $(n=3)$. In this article, we analyse and present previously unpresented data from these studies. The interviews were 
conducted by the authors in the Helsinki metropolitan area in 2010 and 2016. Interviews were conducted in Finnish and all the citations are translated by the researchers. The theme of the interviews was the teachers' pedagogical thinking and pedagogical decision-making. Teachers were not asked directly about the tensions they have faced while planning and implementing their teaching about and from religious narratives, but this was a topic and perspective that the teachers brought forth spontaneously, which can be viewed as an important factor supporting the validity of this study.

For the purposes of aiming at deep and contextual understanding of the various tensions that might be related to the pedagogical use of religious narratives, the case-study methodology is a natural choice. Case is the unit of analysis, which can be an individual or a group of people or a system of action (Tellis 1997). According to Flyvbjerg (2006), "the typical or average case is often not the richest in information". In this study, we regard the Finnish approach to religious education as our case. The Finnish model of non-confessional religious education provided according to the student's own religion is a rather unique "system of action" that serves as an interesting case for the analysis of the interplay between educational values from different frameworks. Furthermore, we have studied this system of action by focusing on the perspectives of the kinds of teachers that we most likely are able to learn from, and who also serve as interesting cases for this study. All these teachers have been teaching for more than 7 years in school and they can be considered as expert teachers as they have taught various age groups and used different pedagogical methods in their teaching. All the teachers participating in this study can be regarded as insiders to the tradition they teach, but they are also committed to the curriculum.

All the interviews were fully transcribed and read through carefully several times. The data was analysed jointly through a process of deductive (research question 1) and inductive (research questions 2 and 3) qualitative content analysis (see e.g. Elo and Kyngäs 2008). For the first research 
question, the basis of deductive, theory-based analysis was Michael Grimmit's classification regarding religious education that can promote education into religion, education about religion or education from religion (Grimmit 1987). Our hypothesis was that in Finnish religious education, the ways teachers use religious narratives should mostly be in the learning about and learning from categories but we wanted to leave open the possibility that also the learning into category would occur; however, all the ways of using the religious narratives could be grouped under the categories learning about and learning from tradition (see table 1).

The research questions regarding different tensions and how teachers resolve these tensions were analysed via inductive, data-based content analysis. All mentions of sacred narratives, such as the narratives of the Bible or the Qur'an or the stories of Hadith, were counted and listed. From these lists, we determined if there were any tension present in the teachers' comments regarding the use of sacred texts in the context of religious education. We understand tension as a situation in which the teacher recognises two or more competing ideals that she or he has to negotiate when using religious narratives as the content or resource of teaching. 7 different types of tensions were discovered, and these were grouped under 3 main categories (see table 2).

\section{Results}

\section{Teaching about and from religious narratives}

In our analysis of the interviews, we categorised different ways of teaching about and from religious narratives in Finnish Lutheran and Islamic religious education (see table 1). 
Table 1 Teaching about and from religious narratives in Finnish Islamic and Lutheran religious education

\begin{tabular}{|c|c|}
\hline Education about religion & Education from religion \\
\hline $\begin{array}{l}\text { Familiarising pupils with religious } \\
\text { stories } \\
\text { - Teaching about the origins and history } \\
\text { of religious narratives } \\
\text { Teaching about the cultural impacts of } \\
\text { religious narratives } \\
\text { - Teaching about the dogma and practices } \\
\text { of religious traditions }\end{array}$ & $\begin{array}{l}\text { - Learning from religious narratives as a } \\
\text { way to promote } \\
\circ \text { ethical thinking } \\
\circ \text { pupils' worldview and life } \\
\text { questions } \\
\circ \text { pupils' personal competences } \\
\text { (e.g. communication and social } \\
\text { skills, emotional skills, critical } \\
\text { thinking) }\end{array}$ \\
\hline
\end{tabular}

All teachers interviewed for this study regarded religious narratives as important content of religious education as the traditions they teach about are largely based on holy scriptures.

Familiarising the pupils with religious narratives was regarded as an important aim in itself, but also the origins and history of narratives were seen as a part of general knowledge regarding religions. Furthermore, the cultural impact of religious narratives were taught. This teaching content included topics such as the impact of religious narratives on festivals and rituals, language and concepts, as well as art and other cultural products such as music, movies and comics. Teachers felt that the use of religious narratives helps pupils understand religious language and expands their vocabulary.

When teaching about the dogma and practices of religious traditions, religious narratives also served as an important source, as teaching about dogma was seen as very abstract and narratives were viewed as a good way to approach the theme:

(...) Well, because there are so many paradoxes in Christianity and how else could you explain a paradox or open up, for example, how it is possible that Jesus is a God and a man except through a story. That is, when you cannot explain why, you have to narrate it. (Teacher 6, LRE). 
IRE teachers discussed the important role of Hadith alongside the Quran because, for example, the practices of praying are found in Hadith. Overall, the teachers' practices of teaching about religious narratives were in congruence with the aims of the national core curriculum, but they also were worried about the fact that knowledge about religious narratives is decreasing, which narrows the pupils' cultural competence of.

In addition to teaching about religious narratives, the teachers taught from religious narratives and used the narratives as resources for the development of various types of learning outcomes (see table 1). Religious narratives serve as premises to ethical thinking both in Islam and Lutheran RE. Although at the curriculum level, this connection is more transparent in Lutheran than in Islamic $\mathrm{RE}$, also the Islamic religious education teachers used sacred narratives as a central resource when teaching about ethics. For instance, tolerance and how to relate to diversity as a Muslim was discussed a lot, and narratives from Hadith were often used as examples. In Lutheran RE, teachers typically narrated the story and afterwards worked with the students in order to translate the ethical message into modern day context. In Islamic RE, the teacher tended to start from a current ethical problem and then draw connections to, for instance, an example given by the prophet Muhammed in Hadith in order to increase the religious prestige of good behaviour.

Religious narratives were also used as sources when dealing with the pupils' worldviews and life questions. Both LRE and IRE teachers felt that using narratives gives pupils the space to make their own interpretations if the atmosphere is permissive. Teacher also felt that teaching from religious narratives would support the pupils' personal competences, such as their skills of sharing their experiences and listening to others. Pupils were encouraged to find connections between the story and their own life events and also to share their thoughts with others. They also reflected on the 
experiences shared by the others, asked for more details and questioned the solutions made by the characters of the story. The use of narratives also promoted critical thinking since the pupils were given the chance to evaluate the values that were present in the narratives and the teachers also encouraged the pupils to compare the image that the narrative gives to the media image, for example, of the prophet Muhammad.

\section{Tensions involved in the pedagogical use of religious narratives}

In our analysis, we identified several tensions in the pedagogical use of sacred narratives (table 2).

Table 2 Tensions involved in the pedagogical use of religious narratives

\begin{tabular}{|c|c|c|c|}
\hline $\begin{array}{l}\text { Tensions related to the pedagogical } \\
\text { use of sacred narratives }\end{array}$ & Identified tension & $\begin{array}{l}\text { Lutheran } \\
\text { RE }\end{array}$ & $\begin{array}{l}\text { Islamic } \\
\text { RE }\end{array}$ \\
\hline $\begin{array}{l}\text { Tensions between student- } \\
\text { centred learning and sacredness } \\
\text { of the narratives }\end{array}$ & $\begin{array}{l}\text {-Presenting sacred characters } \\
\text { interestingly vs. fear of } \\
\text { trivialising sacred characters } \\
\text {-Making narratives } \\
\text { understandable vs. protecting the } \\
\text { authenticity of the narrative }\end{array}$ & $\mathrm{X}$ & X \\
\hline $\begin{array}{l}\text { Tensions between experiential } \\
\text { and creative learning and } \\
\text { sacredness of the narratives }\end{array}$ & $\begin{array}{l}\text {-Visual material to enliven the } \\
\text { narrative vs. respecting } \\
\text { iconoclastic ideas } \\
\text {-Working creatively with the } \\
\text { texts vs. fear of disrespectful } \\
\text { products } \\
\text {-Using drama vs. holiness of } \\
\text { characters prevent using drama }\end{array}$ & $X$ & $\mathrm{X}$ \\
\hline
\end{tabular}




\begin{tabular}{|l|l|l|l|}
\hline $\begin{array}{l}\text { Tensions between teaching liberal } \\
\text { educational values and protecting } \\
\text { the authenticity of sacred } \\
\text { narratives }\end{array}$ & $\begin{array}{l}\text { Teaching about \& from the holy } \\
\text { book comprehensively vs. } \\
\text { choosing only narratives that } \\
\text { promote liberal educational } \\
\text { values }\end{array}$ & $\begin{array}{l}\text {-Encouraging pupils' autonomy } \\
\text { to interpret the narrative vs. } \\
\text { underlining the traditions' } \\
\text { interpretation. }\end{array}$ & $\mathrm{X}$ \\
\hline
\end{tabular}

Under the first category we grouped tensions between student-centred learning and sacredness of the narratives (table 2). For instance, when presenting sacred characters, student-centred learning would demand that pupils can empathise and identify with holy characters, but the sacredness of the text could require that the characters are treated as holy and with distance. This tension was mostly described by Islamic RE teachers, who highlighted the honoured and 'untouchable' role of all prophets, especially that of the prophet Muhammad, in the religion. However, also in Lutheran RE, the teachers contemplated what would be appropriate language for the students to use when talking, for example, about Jesus. One teacher had considered a student's reference to Jesus as "dude" as appropriate since this is an expression of the pupils' everyday language rather than a demonstration of disrespectful attitude. The teacher recognised this kind of language as a sign of religious education becoming more liberal, but she still prioritised bringing the teaching closer to the students' world.

The teachers also experienced tensions between their need to edit and contextualise the texts in order to make them more understandable and the need to protect the authenticity of the text. They felt it was valuable for the pupils to learn the narratives in their original form and important that the students became familiar with the holy books. Still, they found it difficult to make religious 
narratives relevant to the pupils as today's milieu, society and time are so different. In practice, the teachers sometimes shortened the narratives, used easier concepts and explained the circumstances in which the narrative occurs to promote learning and understanding of the narrative.

Under the second category, we grouped tensions between experiential and creative learning and sacredness of the narratives (table 2). The first tension was related to the use of visual teaching material with the narratives. If the teachers of Islamic RE wanted to enliven the narrative, they avoided using pictures with the characters due to the commonness of iconoclastic ideas in the Islamic tradition. Also, they rarely used videos because of the lack of appropriate video material:

Well okay, of course drawing is a critical issue in Islam anyway. So if you want to illustrate some of the Prophets' stories, you cannot draw a human figure, and you cannot draw any of the prophets, so if you watch one of the Islamic TV channels or, let's say, TV in a country where Islam is the dominant religion or the Prophet's story, the prophets are presented with light covering their faces, and you cannot see their faces, because we must not know what they looked like. (Teacher 5, IRE).

Some teachers sought alternative images to enliven the prophets' narratives:

(...) talking about the prophets is a bit challenging because you cannot actually show pictures of them, but you do something similar, so if you are talking about building the Kaaba in Mecca, let's look up the image of Kaaba on the Internet (...) to liven up that story. (Teacher 4, IRE). 
To support active learning, Finnish RE curricula promote experimental, functional, and cooperative methods. In practice, teachers use methods such as drawing, drama and different activation exercises. However, the teachers described tensions between working creatively with the religious texts and the fear of students coming up with disrespectful products: teachers of Lutheran RE mentioned that sometimes the end-results of these creative methods are 'undesirable'. If this happened, the teachers solved the situation by, for example, sending the 'undesirable' picture drawn by the pupil to his/her parents and asking them to discuss with their child why this kind of behaviour is inappropriate. The Islamic RE teachers did not mention these kinds of undesirable products.

All RE teachers reported that one reason for use narratives in their teaching is to help children empathise with the story and identify with the characters and their life choices. The skill of empathy is also one of the objectives of the RE curricula. Teachers of Lutheran RE did not find any problems in using drama to help the pupils became familiar with all the characters of the narrative. It was acceptable, for instance, to play the role of Jesus or an angel in a play. However, the teachers of Islamic RE felt there are tensions in the use of drama as a teaching method in IRE due to the respect for the integrity of the characters, especially the prophets. Teachers told that they would be particularly worried about the reactions of the parents if they were to ask the children portray any of the prophets. Drama, however, is mentioned as one of the teaching methods in RE in the national curriculum. Teachers of Islamic RE told that they have used fictive ethical narratives, but not narratives from the holy scriptures, as sources for drama.

Under the third category, we grouped tensions between the teaching of liberal educational values and protecting the authenticity of the sacred narratives (table 2). Finnish Islamic religious education has previously been observed as a field of negotiation where tensions between liberal 
educational ideals and Islamic educational values have to be reconciled (Rissanen 2014). In this study, we observed, in particular, how these tensions emerge in the pedagogical use of religious narratives. These tensions occur, for instance, when the religious narrative contains issues that are at odds with liberal educational values and the teacher has to balance between protecting the authenticity of the narrative and promoting liberal values. In practice, the teachers participating in this study seemed to negotiate this tension by choosing narratives that best promote liberal educational values, such as tolerance, and by avoiding narratives that are considered to contradict these values. Another way for them to negotiate these tensions was to emphasise that the context should be considered when interpreting the narratives - however, especially the teachers of Islamic RE emphasised that this is not an attempt to reform or "renew" the tradition:

So, the way of delivering the message... that's very important, even though we have the hadith, we have the Quran, or the Sunna, meaning we have the word of the lord and the sayings of Prophet Mohammed. They are very important, we cannot renew them, but the context should be taken into account. We must leave them as they are, I have no authority, I have no power to say that the Hadith should be renewed or the, let alone the Qur'an should be renewed [...] So pedagogy is very important, the didactic competence. (Teacher 7, IRE).

The second tension in table 2 under this category is tension between pupils' liberty to interpret the story and the teachers' desire to underline the 'right way' of interpreting the narrative. Autonomy as a liberal educational value demands giving students space to interpret the texts, but both Islamic and Lutheran religious education teachers felt the need to limit this autonomy, in some respect, for the sake of respecting the ways in which these narratives have been traditionally interpreted. Especially 
the teachers of Lutheran RE were concerned that their pupils would concentrate on irrelevant details of the story and miss the 'message' or teaching of the story.

I also have some experiences that when talking about the events of Easter, the pupils' attention is fixed on the crucifixion and how it happened and where the nails were put and how could it be possible. Then their attention is drawn to something that is not essential. And it is also because Good Friday is not the main point of Easter. I think that if I tell the story, it can be somehow more at the children's own level and they will not get stuck on things that are not so essential. (Teacher 6, LRE).

The teachers of Islamic RE seemed to treat stories associated with the prophets in a way that did not leave much room for interpretation as they would say "we believe that these things actually happened". However, while the teachers of Islamic religious education regarded the interpretation of religious narratives as a highly sensitive issue, they were also very oriented towards teaching how to live as a Muslim in Finland, a practice that was interpreted as an endeavour to build a ground for the emergence of Finnish Islam (Rissanen 2014), and demanded the teachers answer the students' questions concerning the proper interpretation of the narratives in the Finnish context.

\section{Discussion}

In this qualitative case study, we explored how narratives of religious traditions are taught about and from in Evangelic Lutheran and Islamic religious education in the Finnish public schools, what kind of tensions are involved in the pedagogical use of these narratives and how the teachers negotiate these tensions. According to our results, the main objectives of teaching about narratives were familiarising the pupils with religious narratives and their origin and history, the cultural 
impacts of religious narratives and teaching about the dogma and practices of religious traditions. Teaching from religious narratives concentrated mainly on promoting ethical thinking, supporting pupils to ponder on their worldview and life questions, and developing pupils' personal competences like dialogue and social skills, emotional skills and critical thinking.

We found tensions between the ideals of student-centred learning and sacredness of the narratives, experiential and creative learning and sacredness of the narratives and teaching liberal educational values and protecting the authenticity of the sacred narratives. Teachers of Lutheran religious education seem to find the pedagogical use of religious narratives relatively uncomplicated. Teachers of Islamic religious education put more emphasis on the Islamic self-understanding concerning the role of narratives and they have to find different ways to negotiate liberal educational or curricular aims and the ideals of religious tradition. The differences between the tensions of LRE and IRE occur mostly in student-centred and experiential and creative learning, where especially in the IRE, the sacredness or integrity of characters restrict the pedagogical use of narratives; for instance, the IRE teaches felt more uncomfortable with using drama (which is mentioned as a learning method in the Finnish RE curriculum) as a teaching method.

Tensions in the use of religious narratives seem to relate to the specific nature of religious education as a subject. There are norms that are not laid out in the curriculum arising from religious tradition. These norms are related, for instance, to the sacredness of the characters and what kind of behaviour is considered appropriate. As a part of their pedagogical thinking (Kansanen et al., 2000; Rissanen 2012), teachers are negotiating these unwritten norms and take religious traditions' selfunderstanding into account in order to prevent insults to religious values and practices. Since the Finnish education system and national curricula were historically developed in the societal context and are even today marked by Lutheranism, it is obvious that the present curricular norms might be more at odds with Islamic tradition. Still, some of these tensions - such as what is considered appropriate use of language - are also present in Lutheran RE. 
The use of narratives in Finnish RE seems to differ radically from the way the Qur'an is used in traditional Islamic education; memorising parts of Quran is seen as a marker of good citizenship in the Islamic world, whereas in the context of modern secular education, Muslims students feel their Quranic studies are seen 'backwards' (Berglund 2017). If religious education is aimed to support identity negotiations (e.g. Jackson, 2004), there should be bridges to different pedagogical approaches to sacred scriptures; this is even more important when teaching minority students who navigate between the expectations of their families' traditions and liberal educational context in their every-day life (Rissanen 2014).

It seems that when using religious, sacred narratives in the context of religious education, there is no completely neutral way to make them serve pedagogical purposes. Liberal RE exploits religious texts to the extent they can be used to promote modern educational values present in the curriculum. Occasionally, self-understanding of religious tradition conflicts with the pedagogical aims of liberal RE and teachers have to negotiate between these two perspectives. However, it seems that value negotiations do not arise so much from conflicting values but from a slightly different interpretation of, for instance, autonomy (see also Rissanen 2012). It would be interesting to explore if these kinds of tensions occur also in other forms of RE and how students experience these tensions to understand these negotiation processes better.

\section{References}

Barnes, P. 2006. The Misrepresentation of Religion in Modern British (religious)

Education, British Journal of Educational Studies, 54 (4), 395-411. 
Berglund, J. 2017. "Secular Normativity and the Religification of Muslims in Swedish Public Schooling." Oxford Review of Education 43 (5): 524 -535. doi:10.1080/03054985.2017.1352349 http://dx.doi.org/10.1080/03054985.2017.1352349

Clark, C. M., and P. L. Peterson. 1986. “Teachers' Thought Processes”. In Handbook of Research on Teaching, 3rd ed., edited by M. Wittrock, 255-296. New York: Macmillan.

Clark, M. C., and M. Rossiter. 2008. "Narrative Learning in Adulthood.” In Third Update on Adult Learning Theory, edited by S. B. Merriam. New Directions in Adult \& Continuing Education, Vol. 2008, Issue 119: 61-70. DOI: 10.1002/ace.306.

Copley, T. 2007. "The Power of the Storyteller in Religious Education." Religious Education 102 (3): 288-297. doi: 10.1080/00344080701496264

Elo, S., and H. Kyngäs. 2008. “The Qualitative Content Analysis Process.” Journal of Advanced Nursing 62 (1): 107-115. doi: 10.1111/j.1365-2648.2007.04569.x

Education Statistics in Finland 2017. Accessed 13 October 2017.

https://vipunen.fi/en-gb/basic/Pages/Kieli--ja-muut-ainevalinnat.aspx

Fisher, W. R. 1984. "Narration as a Human Communication Paradigm: The Case of Public Moral Argument." Communication Monographs 51: 1-18. 
Finnish National Agency for Education. 2014. Perusopetuksen opetussuunnitelman perusteet [Core Curriculum for Basic Education]. Accessed 17 April 2017. http://oph.fi/download/163777_perusopetuksen_opetussuunnitelman_perusteet_2014.pdf (in Finnish).

Flyvbjerg, B. 2006. "Five Misunderstandings about Case-study Research.” Qualitative Inquiry 12 (2): 219-245.

Geoff, T. 2010. "Is It Learning about and from Religions, Religion or Religious Education? And Is It Any Wonder Some Teachers Don't Get It?” British Journal of Religious Education 32 (2): 93-103. doi: 10.1080/01416200903537399

Grimmit, M. 1987. Religious Education and Human Development: The Relationship between Studying Religions and Personal, Social and Moral Education. Great Wakering: McCrimmons.

Halstead, J.M. and M. J. Taylor. 1996. (eds). Values in Education and Education in Values. London: The Falmer Press.

Jackson, R. 2004. Rethinking Religious Education and Plurality. Issues in diversity and pedagogy. London: RoutledgeFalmer.

Kansanen, P., K. Tirri, M. Meri, L. Krokfors, and J. Husu. 2000. Teachers' Pedagogical Thinking: Theoretical Landscapes, Practical Challenges. Peter Lang Publishing, Incorporated. 
Kallioniemi, A. and M. Ubani. 2016. "Religious Education in Finnish School System”. In Miracle of Education, edited by H. Niemi, A. Toom, and A. Kallioniemi. Rotterdam: SensePublishers.

Martikainen, T. 2010. “Finland.” In Yearbook of Muslims in Europe, edited by J. Nielsen, 187-196. Leiden: Brill.

Nakib, O. 2015. "The Nature of the Aims of Education: Quranic Perspectives." In AlBayan 13 (1): $25-46$.

Pollefeyt, D. and R. Bieringer. 2005. "The Role of the Bible in Religious Education Reconsidered: Risks and Challenges in Teaching the Bible.” International Journal of Practical Theology 9: $117-139$.

Riessman, C. K. 2008. Narrative Methods for the Human Sciences. Thousand Oaks, California: Sage.

Ricoeur, P. 1992. Oneself as Another. Chicago: The University of Chicago Press.

Rissanen, I. L.E. 2014. Negotiating Identity and Tradition in Single-faith Religious Education: A Case Study of Islamic Education in Finnish Schools. Münster: Waxmann.

Rissanen, I. 2012. Teaching Islamic Education in Finnish Schools: A Field of Negotiations. Teaching and Teacher Education 28 (5): 740-749

Rudrum, D. 2006. On the Very Idea of a Definition of Narrative: A Reply to Marie-Laure Ryan. NARRATIVE, Vol. 14, No. 2. 
Sakaranaho, T. 2006. Religious Freedom, Multiculturalism, Islam: Cross-reading Finland and Ireland. Leiden: Brill.

Tellis, W. M. 1997. “Application of a Case Study Methodology.” The Qualitative Report 3 (3): $1-19$

Biography:

MEd Raili Keränen-Pantsu is a researcher at the University of Eastern Finland, School of Applied Educational Science and Teacher Education. She is currently working on her $\mathrm{PhD}$ research which focuses on teachers' pedagogical thinking and narratives used in the context of worldview education.

Dr. Inkeri Rissanen is a lecturer at the University of Tampere, Faculty of Education. Her research interests include religious education, Islamic religious education and multicultural education. 